\title{
Relative influence of sediment variables on mangrove community assembly in Leizhou Peninsula, China
}

\author{
Jing Liu ${ }^{\mathrm{a}, \mathrm{b}}$, Keming Ma ${ }^{\mathrm{a}, *}$, Laiye $\mathrm{Qu}^{\mathrm{a}}$ \\ a State Key Laboratory of Urban and Regional Ecology, Research Center for Eco-Environmental Sciences, Chinese Academy of Sciences, Beijing 100085, China \\ ${ }^{\mathrm{b}}$ Institute of Plant Nutrition and Resources, Beijing Academy of Agriculture and Forestry Sciences, 100091, China
}

\section{A R T I C L E I N F O}

\section{Article history:}

Received 28 November 2016

Received in revised form 3 February 2017

Accepted 4 February 2017

Available online 13 February 2017

\section{Keywords:}

Canonical correspondence analysis

Mangrove vegetation

Sediment physicochemical variables

Heavy metal

Variation partitioning

Significant variables

\begin{abstract}
A B S T R A C T
Effective conservation of mangroves requires a complete understanding of vegetation structure and identification of the variables most important to their assembly. Using canonical correspondence analysis (CCA) combined with variation partition, we determined the independent and joint effects of sediment variables, including physicochemical characteristics and heavy metals, on mangrove community assemblies in the overstory and understory in Leizhou Peninsula, China. The results indicated that the contributions of sediment physicochemical variables to community assembly were greater than were those of heavy metals, particularly in overstory vegetation. However, the independent contributions of heavy metals were higher in understory mangrove vegetation than in the overstory. The TOC, TP, and salinity of the sediment, distance from the coastline, and concentration of As were limiting factors for mangrove assembly in overstory vegetation, while understory vegetation may be affected to a greater degree by the distance from the coastline, electrical conductivity, and concentration of As and $\mathrm{Pb}$ in the sediment.
\end{abstract}

(c) 2017 Elsevier Ltd. All rights reserved.

\section{Introduction}

Mangrove vegetation encompasses a group of trees or shrubs that grow in the tidal waters along tropical and subtropical coastlines. The mangrove ecosystem provides important services, such as food, wood, chemical pharmaceutical production, and other aesthetic values, and offers such critical ecological functions as coastal protection, land stabilization, water purification, and $\mathrm{CO}_{2}$ fixation. However, mangroves often are located in fragile habitats, and very few mangrove systems can be restored to their original state once they have been destroyed (Tam and Wong, 2000). It has been shown that most remaining coastal wetlands have been degraded or altered because of land conversion or altered hydrodynamic and sediment conditions, and will continue to be lost throughout the twenty-first century (Duke et al., 2007; Friess et al., 2012). Effective conservation of mangrove systems, including protective regulations and restoration efforts, require comprehensive knowledge of the vegetation structure of these forests, the identification of variables important to them, and an understanding of their interactions.

A range of factors that influence mangrove vegetation has been studied. For example, the degree of tidal inundation may play an

\footnotetext{
* Corresponding author at: State Key Laboratory of Urban and Regional Ecology, Research Center for Eco-Environmental Sciences, Chinese Academy of Sciences, Beijing 10085, China.

E-mail address: mkm@rcees.ac.cn (K. Ma).
}

important role in structuring mangrove distribution (Satyanarayana et al., 2002). Soil redox potential, salinity, pH, and concentrations of nutrients, sulfide, and phytotoxins also serve as important determinants of mangrove vegetation (Mckee, 1995; Krauss et al., 2008). Further, mangrove seedling distributions have been shown to be attributable to dispersal patterns in the intertidal zone, which appear to be controlled by physicochemical variables (Mckee, 1995). Canopy and substratum heterogeneity also influence the recruitment of the mangrove Avicennia marina (Minchinton, 2001).

In additional, heavy metals, primarily from industrial areas, commonly are retained within mangrove sediments (Machado et al., 2002). Uptake of excess metals by mangroves can initiate sub-cellular metabolic reactions that may cause damage at the cellular level or lead to whole plant phytotoxic responses, including visible inhibition of growth and increased mortality. Photosynthetic pigments and peroxidase activity are sensitive biological indicators of $\mathrm{Cu}, \mathrm{Zn}$, and $\mathrm{Pb}$ stress in Avicennia marina (MacFarlane and Burchett, 2002). MacFarlane and Burchett reported an $\mathrm{LC}_{50}$ of $580 \mu \mathrm{g} / \mathrm{g}$ zinc (artificial sediments incubated with zinc [II] for 2 weeks) for A. marina seedlings; this value approaches the upper range of total zinc reported for some mangrove sediment samples (MacFarlane and Burchett, 2002; Bayen, 2012).

Overall, a variety of factors affects mangrove species assembly, and these variables often are correlated highly. However, only a few studies have examined the independent and joint effects of these potential variables on mangrove vegetation. Ordination algorithms are an appropriate choice to explore the relation between vegetation development and 
environmental variables (Dahdouh-Guebas et al., 2002), and are useful in examining the relative importance of these explanatory variables and their independent and joint effects.

Thus, in this study, two sets of possible explanatory variables for mangrove vegetation were determined: (1) the physicochemical characteristics of the habitat, and (2) the concentrations of heavy metals in the habitat sediment. We conducted repeated analyses in the overstory and understory of the mangrove vegetation, respectively. And constrained ordination combined with variation partitioning among sets of explanatory variables was applied to examine the relative importance of these variables and their independent and joint effects (Matthews et al., 2009; Li et al., 2016). The purpose of this study was to explore the dominant variables that contribute to the mangrove community assemblies in the overstory and understory and to examine their relative importance in Leizhou Peninsula, China. This type of research can generate results that may be important for mangrove conservation and management objectives (e.g., the establishment, protection, and management of afforestation).

\section{Methods}

\subsection{Study sites and sampling}

The study was conducted on the Leizhou Peninsula, which shelters the largest natural mangrove reservoir in China and is governed by Zhanjiang, Guangdong (Gao et al., 2009). The mean annual precipitation and evaporation in this area are approximately $1390-1760 \mathrm{~mm}$ and $1700-2200 \mathrm{~mm}$, respectively, with a mean annual temperature of 22$23{ }^{\circ} \mathrm{C}$ (Rumisha et al., 2012). The area supports 22 mangrove species, including 13 true mangrove species, and nine semi-mangrove species (Parker, 1997).

Representative study locations were selected based on information from Zhanjiang Mangrove National Nature Reserve and field surveys. Twenty-six sites dominated by forested mangrove communities were selected randomly (Fig. 1). We sampled at low tide from the middle of October through November 2012. Sampling site geo-positions (latitude and longitude) were determined using a Garmin global positioning system with a spatial accuracy of approximately $\pm 5 \mathrm{~m}$. Distances from the sampling sites to the coastline were calculated in ArcGIS 10.0 with data from satellite images.

At every site, a sample transect was established parallel to the shoreline, with three sub-sample plots $(10 \times 10 \mathrm{~m}$ size $)$. In every sub-sample plot, all mangrove individuals were identified and their number, diameters (at $1.3 \mathrm{~m}$ for adults, at half-height for plants under $2 \mathrm{~m}$ tall, and above the uppermost intersection of the prop roots for Rhizohpora) (Fromard et al., 1998; Stephen and Han, 2008), height, and crown diameter were recorded. In understory vegetation, all plant species $(<1.3 \mathrm{~m}$ in height (Alatalo, 1981; Stephen and Han, 2008)) were identified and measured in terms of abundance (number of individuals), coverage, and height within the sub-plot $(5 \times 5 \mathrm{~m}$ size $)$.

Further, in each sub-sample plot, three sediment cores $15 \mathrm{~cm}$ deep and $5 \mathrm{~cm}$ in diameter were collected randomly around the roots of mangroves using a homemade stainless sediment core sampler and mixed to obtain one homogenized sample. All sediment samples were packed in plastic bags and transported to the lab immediately. The samples were air dried and sieved through a 2-mm plastic sieve; stones and plant debris were removed with tweezers. Approximately $20 \mathrm{~g}$ of each sample were ground in an agate mortar and passed through a $150-\mu \mathrm{m}$

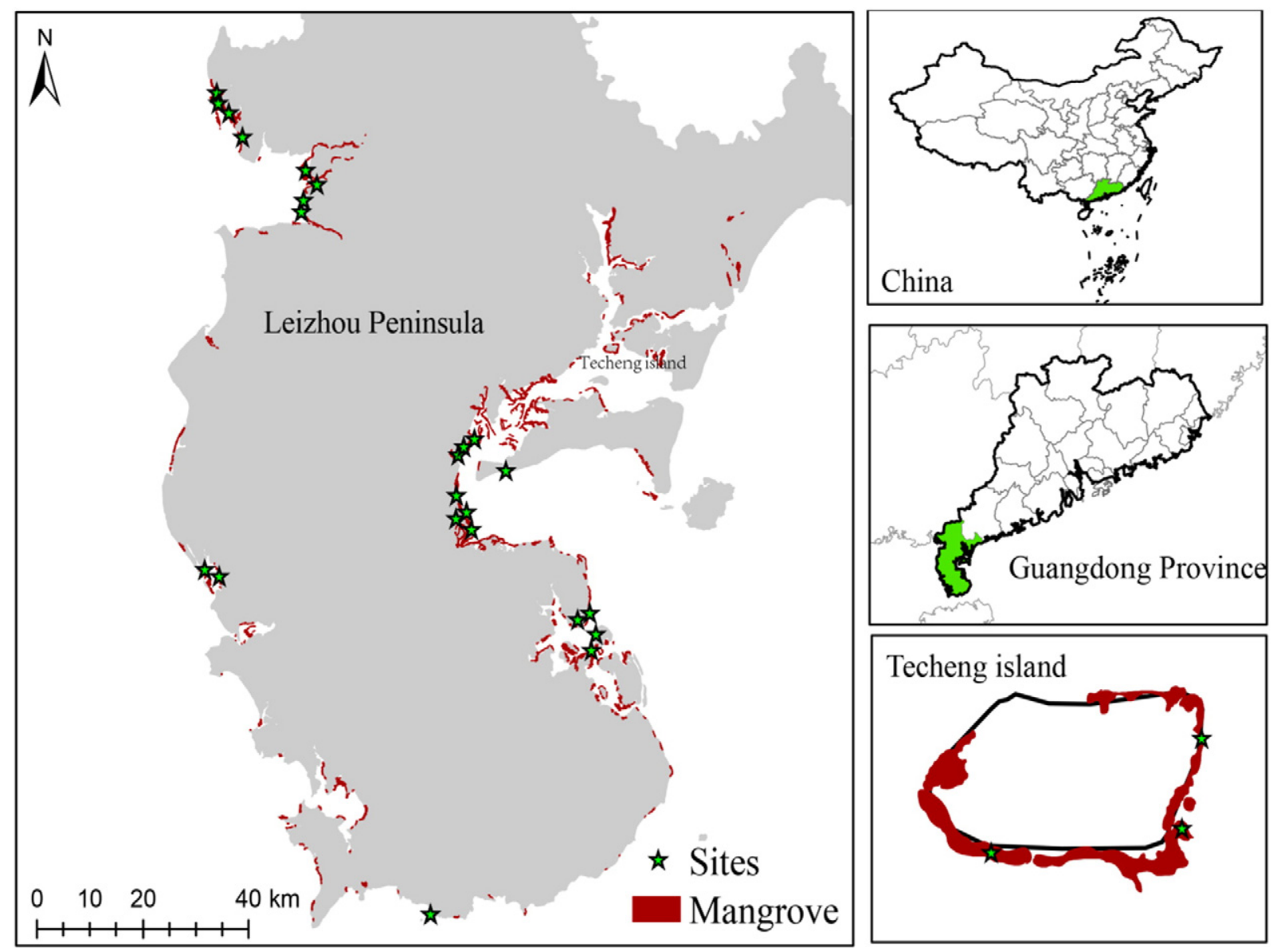

Fig. 1. Location of sampling sites in mangrove swamp in Leizhou Peninsula, China. 
polyethylene sieve. Samples were sealed in polyethylene bags and stored in a desiccator prior to chemical analyses.

\subsection{Analytical methods}

\subsubsection{Plant community analysis}

All plant community data were used to calculate an importance value (the sum of the relative height, coverage, and abundance, divided by three) (Alatalo, 1981; Zhang et al., 2006) for all species in the overstory and understory, respectively. Species found in fewer than three sites were eliminated prior to analysis of SIV (species importance values), which ultimately left 6 species for analysis in the overstory and 7 in the understory. Intentional planting is an important component of mangrove wetland restoration, and planted species can influence the establishment of volunteer species (Streever and Zedler, 2000; Armitage et al., 2006). We thus retained all species planted intentionally in the analysis.

\subsubsection{Determination of sediment physicochemical variables}

Physicochemical variables in sediment include salinity, electrical conductivity (EC), total organic carbon (TOC), total sulfur (TS), total potassium (TK), total phosphorus (TP), and total nitrogen (TN). The salinity and EC of the sediment were measured in the field with a hand-held Conductivity/TDS Meter (Oakton, CON110). Each soil sample was air dried, ground, and passed through a 2-mm sieve. TOC was measured with a TOC analyzer (vliquiTOC II, Elementar). TN was determined by the element analyzer, vario MAX CN (Elementar). TP was analyzed with an inductively coupled plasma-mass spectrometer (ICP-MS, 7500 CX, Agilent, USA). TK and TS were measured using an inductively coupled plasma-optical emission spectrometry (ICP-OES, 7000DVM Oerjub Elmer, USA).

\subsubsection{Analysis of heavy metal in sediments}

Approximately $0.2 \mathrm{~g}$ of a sample were digested in a microwave oven (Anton-Paar PE Multiwave 3000) with a highly purified, concentrated acid mixture of $4 \mathrm{ml}$ nitric acid $\left(\mathrm{HNO}_{3} ; 68 \%\right), 1.5 \mathrm{ml}$ perchloric acid $\left(\mathrm{HClO}_{4}\right)$, and $2 \mathrm{ml}$ hydrofluoric acid (HF). The solution of the digested samples was analyzed with the inductively coupled plasma-mass spectrometer to measure the content of $\mathrm{As}, \mathrm{Cu}, \mathrm{Pb}, \mathrm{Zn}, \mathrm{Cr}, \mathrm{Cd}$, and $\mathrm{Ni}$. The metal analyses were conducted in triplicate. The analytical quality was assessed using standard reference materials (GBW 07401 from Chinese Academy of Measurement Sciences) and reagent blanks. All results showed good agreement with certified data and were verified accurately and precisely.

\subsubsection{Statistical analyses}

Initial detrended correspondence analyses (DCA) indicated that the gradients in species assemblies in overstory and understory vegetation among sites were all long (>3.0) for ordination (Lepš and Šmilauer, 2003). Therefore, we used canonical correspondence analysis (CCA) to partition the variation in the mangrove species assemblies among the sites. Analyses were repeated with mangrove SIV for overstory and understory vegetation, respectively. We first performed ordinations constrained by each set of predictors separately, and then performed partial ordinations to determine (1) the amount of variation attributable to each set of predictors independently, and (2) the amount of variation shared among sets of predictors. To determine significant variables, we applied forward selection by the permutation of residuals at the $5 \%$ significance level. Variation partitioning was performed using only these significant variables.

All statistical analyses were conducted in $R$ (version 3.0.3) with "Vegan" packages (Oksanen et al., 2013). The results are presented in an ordination diagram in which arrows represent all variables. A smaller angle between arrows represents a high correlation between variables, and the direction of the arrows represents positive or negative correlations.

\section{Results}

\subsection{Species composition and sediment characteristics}

In this study, we found seven species in the overstory and ten species in the understory at twenty-six sampling sites in Leizhou Peninsula, China, including six true mangrove species. The height, coverage, abundance, and diameter (or basal diameter) of every species are listed in Table 1. Excoecaria agalloch in the overstory and Sonneratia apetala Buch. Ham, Excoecaria agalloch, and Paederia scandens (Lour.) Merr. in the understory were eliminated from SIV and correspondence analyses, as they were found in fewer than three sampling sites. The remaining six species in the overstory are all true mangrove species. Remarkably, composition was co-dominated by Sonneratia apetala Buch. Ham, Rhizophora stylosa and Avicennia marina with high SIV. Table 1 shows that Sonneratia apetala Buch. Ham had lower abundance, but the greatest height and diameter at breast height (DBH). Rhizophora stylosa and Aegiceras corniculatum had higher abundance, and the height and DBH of Avicennia marina were relatively high. In the understory, the composition was co-dominated by seedlings of Aegiceras corniculatum and Avicennia marina with high SIV. The height values among the seven species in the understory did not differ significantly. Further, the abundance of Aegiceras corniculatum was significantly highest, followed by Aegiceras corniculatum. However, coverage values of Avicennia marina were lower than were those of Aegiceras corniculatum. In twenty-six sampling sites, the average distance to coastline calculated from satellite images was $78.8 \mathrm{~m}$, while the distance from sites with dominant Sonneratia apetala Buch. Ham to coastline was $109.2 \mathrm{~m}$. Additionally, sediment TOC (range $=0.17-3.83 \%$ ), TS (range $=0.01-3.04 \%$ ), $\mathrm{TN}$ (range $=0.06-0.26 \%)$ and TP $($ range $=52.79-755.75 \mathrm{ppm})$ showed greater variation among sampling sites, while soil salinity (range $=$ $1.45-8.77 \mathrm{ppt}$ ) was very low and did not vary significantly among plots. In addition, Zn (59.49 ppm, range $=15.51-135.56 \mathrm{ppm}$ ) showed the highest mean concentration, followed by As (38.77 ppm, range $=$ 26.56-52.06 ppm), Cr (33.85 ppm, range $=5.398-117.966 \mathrm{ppm}), \mathrm{Pb}$ (23.49 ppm, range $=4.117-59.728 \mathrm{ppm}), \mathrm{Ni}(15.41 \mathrm{ppm}$, range $=$ $1.838-76.602 \mathrm{ppm}), \mathrm{Cu}(11.52 \mathrm{ppm}$, range $=2.674-36.810 \mathrm{ppm})$, and Cd $(0.18 \mathrm{ppm}$, range $=0.043-0.360 \mathrm{ppm})$.

\subsection{Plant assembly in overstory vegetation}

CCA of the species assembly in overstory vegetation using sediment physiochemical characteristics separated out four significant factors: TOC $(p=0.036)$, distance $(p=0.002)$, TP $(p=0.047)$, and salinity $(p=0.001$ : Fig. 2A). With analysis of variation partitioning, TOC, distance, TP, and salinity accounted for $5.38 \%, 7.52 \%, 2.45 \%$, and $6.90 \%$ of the variation in mangrove assembly, respectively. Along CCA axis 1 , sites farther from the coast had high coverage of the planted Sonneratia apetala Buch. Ham, while sites near the coastline had high coverage of Avicennia marina. Along axis 2, sites with a high concentration of TOC and salinity had a high abundance of Aegiceras corniculatum, as well as a high concentration of TP.

The metal concentration in the sediment also was associated with the mangrove species assembly. As ( $p=0.001)$ was the only significant factor among seven metals (Fig. 2B), and explained 9.33\% of the variation in the species assembly. Along CCA axis 1 , sites with high concentrations of As had a high abundance of Rhizophora stylosa and Aegiceras corniculatum.

Ordination constrained by physicochemical variables and heavy metals in sediment all resulted in a statistically significant relationship with mangrove species assembly in the overstory (Table 2). All significant variables explained $25.74 \%$ of the total variation in species assembly. Total variation was partitioned into independent and joint effects for each set of explanatory variables. The independent contributions of sediment physicochemical variables were $18.39 \%$, larger than the 
Table 1

Quantity characteristics of mangrove species in the overstory and understory in mangrove swamp in Leizhou Peninsula, China.

\begin{tabular}{|c|c|c|c|c|c|}
\hline Overstory & $\begin{array}{l}\text { Abundance } \\
\text { (number } / 100 \mathrm{~m}^{2} \text { ) }\end{array}$ & $\begin{array}{l}\text { Height } \\
(\mathrm{m})\end{array}$ & $\begin{array}{l}\text { Diameter } \\
(\mathrm{cm})\end{array}$ & $\begin{array}{l}\text { Coverage } \\
\left(\mathrm{m}^{2}\right)\end{array}$ & Importance values \\
\hline Avicennia marina & $0-74$ & $1.3-6.0$ & $0.63-11.3$ & $0.14-3.55$ & 0.203 \\
\hline Rhizophora stylosa & $0-299$ & $1.3-5.29$ & $0-9.68$ & $0.78-3.15$ & 0.223 \\
\hline Bruguiera gymnorrhiza & $0-44$ & $1.3-5.6$ & $2.1-23.60$ & $0.8-3.44$ & 0.033 \\
\hline Kandelia candel & $0-116$ & $1.33-6.0$ & $1.09-8.85$ & $0.71-4.0$ & 0.127 \\
\hline Aegiceras corniculatum & $0-283$ & $1.38-3.81$ & $1.29-4.98$ & $0.32-1.13$ & 0.078 \\
\hline Sonneratia apetala Buch.Ham & $0-86$ & $3.77-13.54$ & $5.29-22.20$ & $1.70-5.63$ & 0.336 \\
\hline Excoecaria agalloch & $0-1$ & $2.9-2.9$ & $1.15-1.15$ & $1.08-1.08$ & - \\
\hline Understory & Abundance (number/25 $\mathrm{m}^{2}$ ) & Height $(\mathrm{m})$ & Basal diameter $(\mathrm{cm})$ & Coverage $\left(\mathrm{m}^{2}\right)$ & Importance values \\
\hline Avicennia marina & $0-279$ & $0.1-1.2$ & $0.2-2.8$ & $0.05-0.95$ & 0.282 \\
\hline Rhizophora stylosa & $0-83$ & $0.18-1.2$ & $0.4-3.1$ & $0.09-1.25$ & 0.070 \\
\hline Bruguiera gymnorrhiza & $0-11$ & $0.3-1.28$ & $0.8-2$ & $0.13-0.78$ & 0.081 \\
\hline Kandelia candel & $0-87$ & $0.29-1.3$ & $0.61-9.1$ & $0.07-1.5$ & 0.190 \\
\hline Aegiceras corniculatum & $0-115$ & $0.13-1.3$ & $0.18-3.8$ & $0.04-2.98$ & 0.3267 \\
\hline Sonneratia apetala Buch.Ham & $0-2$ & $0.41-1.2$ & $2-3.6$ & $0.29-0.65$ & 0.026 \\
\hline Derris trifoliata Lour. & $0-1$ & 1.3 & 0.3 & 0.25 & 0.024 \\
\hline Spartina alterniflora Loisel. & $0-49$ & $0.2-0.5$ & & & - \\
\hline Excoecaria agalloch & $0-2$ & $0.9-1$ & 1.15 & 0.52 & - \\
\hline Paederia scandens (Lour.) Merr. & $0-4$ & $0.94-1.2$ & 1.7 & 0.54 & - \\
\hline
\end{tabular}
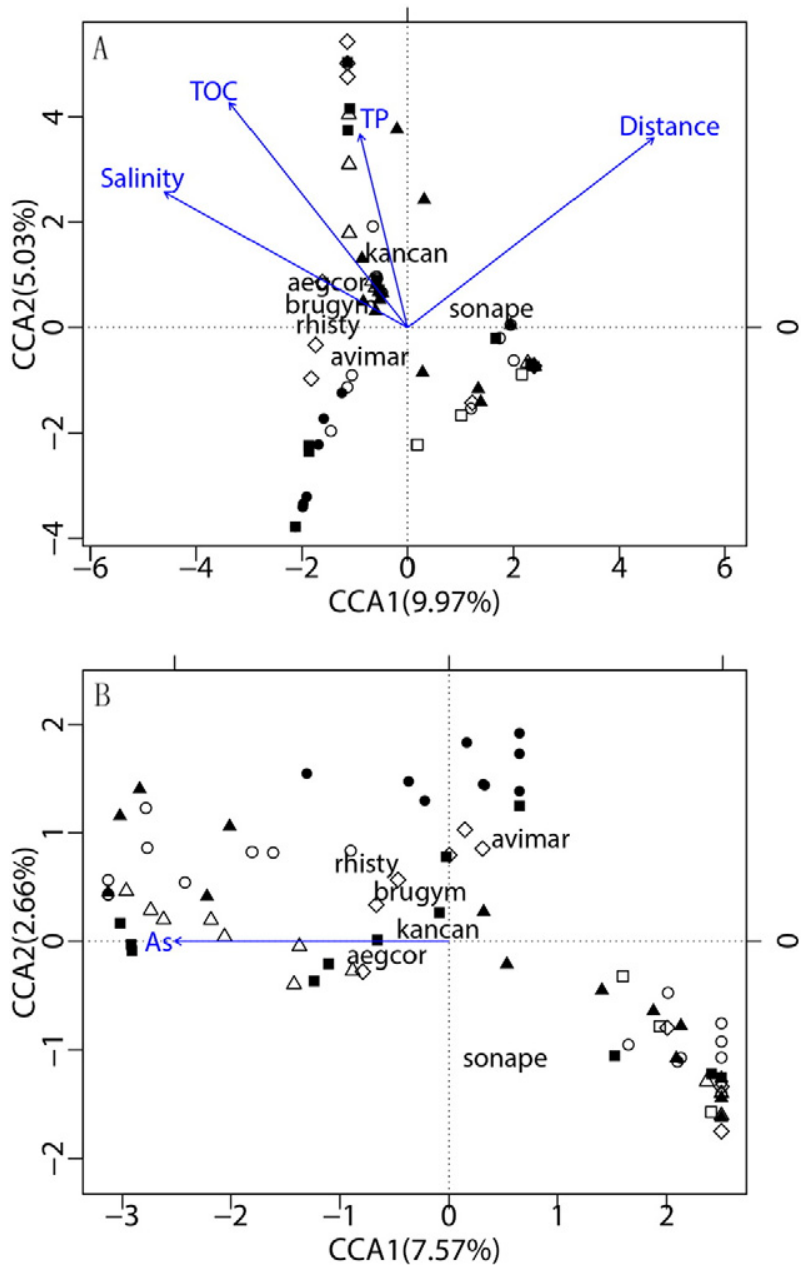

Fig. 2. Biplots from a canonical correspondence analysis (CCA) ordination plot showing the relationship of mangrove species assembly in the overstory with physicochemical variables (A) and heavy metals (B) in sediment. Abbreviations are: EC, electrical conductivity; TOC, total organic carbon; and TP, total phosphorus. avimar, Avicennia marina; sonape, Sonneratia apetala Buch. Ham; aegcom, Aegiceras corniculatum; kancan, Kandelia candel; rhisty, Rhizophora stylosa; brugym, Bruguiera gymnorrhiza. Sites are: Techeng island; $\bigcirc$ Leizhou; $\diamond$ Mazhang; $\square$ Donghai island; $\square$ Suixi; $\Delta$ Xuwen; $\Delta$ Lianjiang. contributions of heavy metals (7.57\%). In addition, the joint effects of physicochemical variables and sediment metals were $1.22 \%$.

\subsection{Plant assembly in understory vegetation}

The CCA that predicted mangrove species assembly in the understory using sediment physicochemical variables produced a biplot similar to that for the overstory vegetation. $\mathrm{EC}(p=0.009)$ and distance ( $p=0.001$ ) were significant factors (Fig. 3A), and accounted for $3.96 \%$ and $3.81 \%$ of the variation in species assembly, respectively. Some sites located far from the sea with abundant Sonneratia apetala Buch. Ham had high scores along the first axis. Nevertheless, sites with high scores along the second axis were associated with high EC and dominated by Rhizophora stylosa.

We found significant correlations between species assembly in understory vegetation and sediment metals (Fig. 3B). As $(p=0.001)$ and $\mathrm{Pb}(p=0.039)$ were significant variables, and explained $5.03 \%$ and $4.59 \%$ of the variations in species assembly, respectively. Along CCA axis 2, some sites had high concentrations of $\mathrm{As}$ and $\mathrm{Pb}$ associated with Aegiceras corniculatum.

Ordination constrained by sediment physicochemical variables and heavy metals all resulted in a statistically significant relationship with mangrove species assembly in the understory (Table 2), and two sets of variables together explained $20.93 \%$ of the variation in species assembly. The independent contributions of sediment physicochemical variables and heavy metals were similar $(11.8 \%$ and $11.46 \%$ of the total variation, respectively). Further, the joint effect from these two sets of habitat variables on species assembly was $2.33 \%$.

Table 2

Results of variation partitioning using partial ordinations to determine the influence of two sets of variables on mangrove species composition in the overstory and understory.

\begin{tabular}{|c|c|c|c|c|}
\hline \multirow{2}{*}{$\begin{array}{l}\text { Effect and main } \\
\text { variables }\end{array}$} & \multicolumn{2}{|l|}{ Overstory } & \multicolumn{2}{|l|}{ Understory } \\
\hline & $\begin{array}{l}\text { Explanation of } \\
\text { variation }\end{array}$ & $\begin{array}{l}p \\
\text { value }\end{array}$ & $\begin{array}{l}\text { Explanation of } \\
\text { variation }\end{array}$ & $\begin{array}{l}p \\
\text { value }\end{array}$ \\
\hline \multicolumn{5}{|l|}{ Total effect } \\
\hline Set 1 & 18.39 & 0.001 & 11.8 & 0.001 \\
\hline Set 1 , Set 2 & 25.74 & 0.001 & 20.93 & 0.001 \\
\hline Set 2 & 7.57 & 0.001 & 11.46 & 0.001 \\
\hline \multicolumn{5}{|l|}{ Joint effects } \\
\hline Set 1 and Set 2 & 1.22 & - & 2.33 & - \\
\hline
\end{tabular}

Note: Set 1 , the physicochemical variables in sediment. Set 2 , heavy metal variables in sediment. 

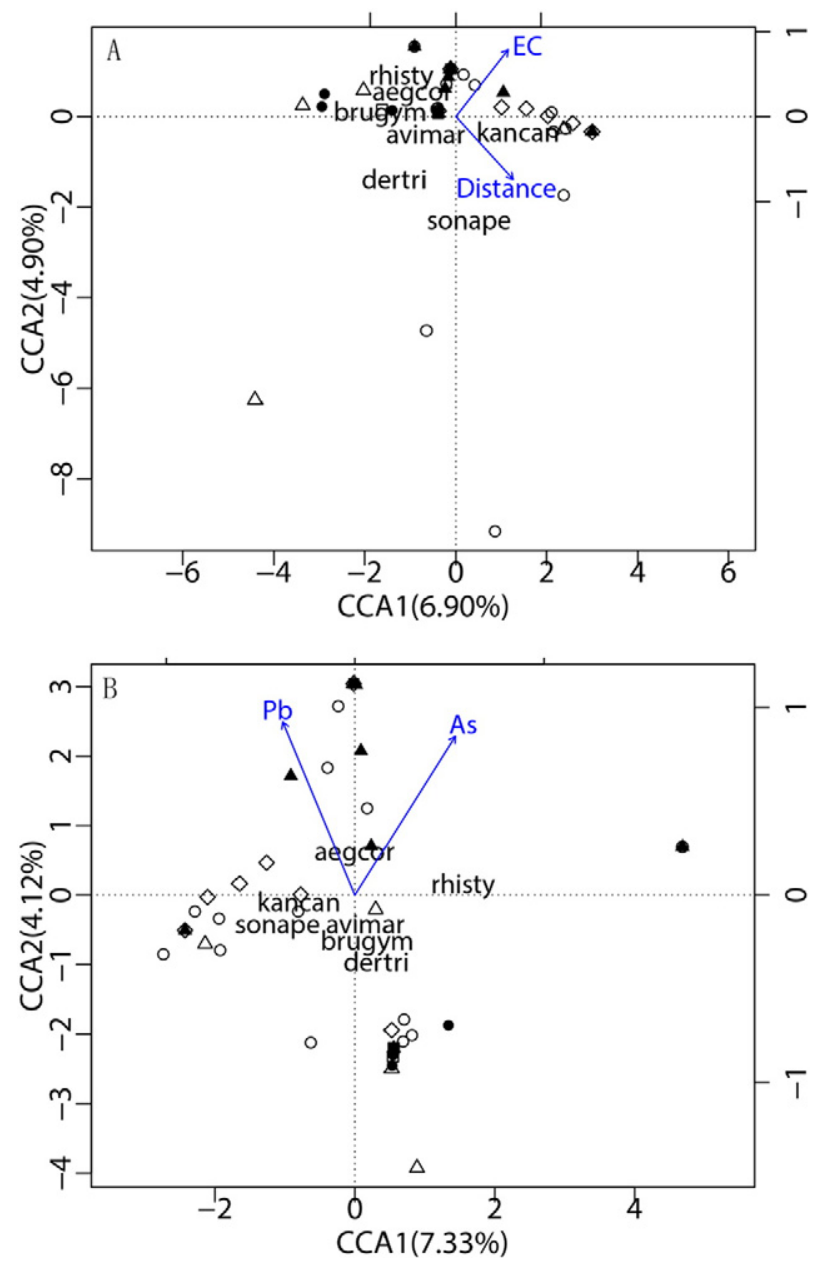

Fig. 3. Biplots from canonical correspondence analysis (CCA) ordination plot showing the relationship of mangrove species assembly in the understory with physicochemical variables (A) and heavy metals (B) in sediment. Abbreviations are: TOC, total organic carbon; avimar, Avicennia marina; brugym, Bruguiera gymnorrhiza; aegcom, Aegiceras corniculatum; kancan, Kandelia candel; rhisty, Rhizophora stylosa; sonape, Sonneratia apetala Buch. Ham; excaga, Excoecaria agalloch. Sites are: - Techeng island; O Leizhou; $\diamond$ Mazhang; $\square$ Donghai island; $\mathbf{\square}$ Suixi; $\Delta$ Xuwen; $\Delta$ Lianjiang.

\section{Discussion}

The CCA analysis in this study enabled us to assess the relative contribution to mangrove species assembly of multiple factors in sediments. Mangrove species' development in different growth stages is affected by specific factors. This study demonstrated the appropriate variables to choose in the different vegetation layers in efforts to protect mangrove.

\subsection{Effect of sediment physicochemical variables on mangrove community assembly}

The distance from the coastline was a significant variable that explained the higher percentage of variation in mangrove species assembly both in the overstory and understory. In study, the distance was calculated in ArcGIS 9.3 with data from satellite image, reflecting the relative distance of all sampling sites from the coastline. Sites proximate to the coastline represents are at low elevations, where flooding is more frequent, and the drag forces waves and currents exert on seedlings are higher (Friess et al., 2012). Mangroves depend primarily on seedling recruitment for forest maintenance and spread (Tomlinson, 1986). Both the establishment and survival of seedlings affect species distribution and abundance patterns directly (Mckee, 1995), and initial seedling survival depends on resistance to these drag forces. Pioneer species, particularly Avicennia marina, have evolved growth form and life history characteristics to reduce drag forces and dislodgment in hydrodynamic environments, such as flexible seedling stems and foliage predominantly at the tip of the seedling (Friess et al., 2012). Therefore, Avicennia marina is known to be an important pioneer along the open coastline located in the lower intertidal region (Tomlinson, 1986; Satyanarayana et al., 2002; Giesen et al., 2007), and is correlated negatively with the distance variable. Distance from the coastline appeared to have no significant effects on Rhizophora stylosa, Kandelia candel, Aegiceras corniculatum, and Bruguiera gymnorrhiza, which often are located in the middle intertidal region; this agrees with Satyanarayana et al. (2002). However, Sonneratia apetala Buch. Ham showed a positive correlation with distance, which contradicts his results (Satyanarayana et al., 2002). In Southeast Asia, Sonneratia alba may be associated spatially with Avicennia spp. in the pioneer zone (Thampanya et al., 2002), although it also can be found further seaward because of its ability to spread vegetatively in a manner similar to that of Spartina spp., especially on muddy substrata (Friess et al., 2012). Nevertheless, in China, Sonneratia apetala Buch. Ham, which was introduced in 1985 and occupies approximately $95 \%$ of the mangrove restoration area (Wang and Wang, 2007), is planted in the upper intertidal zone far from the coastline.

Soil salinity had significant effects on species assembly in mangrove vegetation, which agrees with Koch, who stated that soil salinity limits the development of mangrove forests (Koch and Snedaker, 1997). In our study, salinity was correlated significantly with variation in the species assembly in the overstory, and was particularly positive with Kandelia candel and negative with Sonneratia apetala Buch. Ham. Previous results have shown that salinity affects mangrove production and growth form, as well as mortality (Kao et al., 2001). Increased salinity decreases height and growth and increases mortality (Suárez and Medina, 2005; Lara and Cohen, 2006; Laura et al., 2007). The optimal range in salinity for $K$. candel is between 5 and 15 ppt, and salinity levels over 20 ppt inhibit the growth (Zheng and Lin, 1990) and photosynthesis of seedlings (Li et al., 2008; Ye et al., 2010). The sediment salinity in this study ranged between 1.45 and $8.77 \mathrm{ppt}$, which is not excessively high for Kandelia candel. Similarly, average seawater salinity for Kandelia candel in Jiulong River Estuary, Fujian, China is 2.16 ppt (Lin, 1987). In China, most Sonneratia apetala Buch. Ham is planted in the high intertidal area, where stresses from flooding and salinity are minimized, which may be the reason for its negative correlation with salinity. However, in the understory vegetation, EC, not salinity, had a significant effect on species assembly. Previous studies have shown that the EC method is a simple and rapid one with which to measure soil salinity after defining the regression equation between soil salinity and EC (Zhang et al., 2003). Therefore, EC could reflect the correlations between mangrove species in understory and salinity indirectly.

Nutrient limitations have been shown to vary spatially, even where there is no strong salinity gradient (Lovelock et al., 2006). In various studies, TP has been found to correlate significantly with mangrove species assembly in the overstory, which agrees with Koch and Snedaker (1997) and Feller (1995), who showed that without hyper-salinity stress, phosphorous rather than nitrogen is a dominant factor that limits foliar and stem development. Further, TP also affects spatial and temporal patterns of microbial community structure, activity, and likely plantmicrobe interactions, which affect mangrove growth indirectly (Romero et al., 2012). Similarly, TOC is a significant variable for mangrove species assembly in the overstory. Mangrove litter is the primary source of organic matter (Kristensen et al., 2008). Reduction in water movement in the interior mangrove areas increases deposition of fine sediments that hold a greater amount of organic matter because of the high surface area (Krishna Prasad and Ramanathan, 2008). Hence, in the interior mangrove sediments, where Aegiceras corniculatum, Kandelia candel, and Bruguiera gymnorrhiza are located, organic matter levels are higher than in the estuarine sediments. Furthermore, TOC is also an important driver of the structures of microbial communities, 
which influence nutrient availability for mangroves (Romero et al., 2012).

Total canopy not only describes the effect of trees on shrubs in mangrove swamps, but also reflects indirectly the light coming through gaps. Long-term survival of seedlings and their development into saplings may depend on the light availability in these gaps (Duke, 2001). In this study, total canopy had no significant effects on species assembly, which contradicts previous results (Duke, 2001; Minchinton, 2001; Laura et al., 2007). The reason for this discrepancy is, perhaps, the absence of significant variation in the canopy among sampling sites.

\subsection{Effect of sediment metals on mangrove community assembly}

As had a significant effect on mangrove species in both overstory and understory vegetation, and ranged from 26.56 to $52.06 \mu \mathrm{g} / \mathrm{g}$ dry weight in this study. Comparing this with sediment quality guidelines, threshold effect concentrations (TEC of As is $9.79 \mu \mathrm{g} / \mathrm{g}$ dry weight) and probable effect concentrations (PEC of As is $33 \mu \mathrm{g} / \mathrm{g}$ dry weight) (MacDonald et al., 2000), As is of greatest eco-toxicological concern in Leizhou Peninsula and is likely to have harmful effects on sediment-dwelling organisms. As enters wetlands through both point and diffuse sources that may be natural or anthropogenic. Important anthropogenic sources are mining and related industrial activities and the use of arsenicals as pesticides and herbicides (Carbonell et al., 1998). Leizhou Peninsula is mineral-rich, especially in the western region, where the concentration of As is high (Gan et al., 2014). In addition, agriculture is the primary economic activity in Zhanjiang. As cannot be eliminated from sediments, but it can change forms. Speciation is important in the study of the environmental behavior of As, as major features affect its uptake, transport, and toxicity to plants (Quaghebeur and Rengel, 2005). Therefore, future studies should be conducted on the effects of As speciation on mangrove species.

$\mathrm{Pb}$ also has effects on mangrove species assembly in understory vegetation. However, mature mangrove trees have no significant correlation with $\mathrm{Pb}$, and it is possible that mangrove seedlings are more sensitive to this heavy metal. For example, most of the effects of pollution on mangrove plants have been conducted on mangrove seedlings using biological responses, such as survival, biomass production, defoliation and photosynthesis, expression of metallothioneins (MT), activities of enzymes (e.g., GSHH, SOD, CAT, peroxidase), lipid peroxidation products, and mutation frequency (Dahdouh-Guebas et al., 2002). Pb concentration in Leizhou Peninsula ranged from 4.12 to $59.73 \mu \mathrm{g} / \mathrm{g}$ dry mass. According to TEC (TEC of Pb is $35.8 \mu \mathrm{g} / \mathrm{g}$ dry mass) and PEC (PEC of $\mathrm{Pb}$ is $128 \mu \mathrm{g} / \mathrm{g}$ dry mass), almost $20 \%$ of sampling sites are above TEC, but all are below PEC, which indicated that there is a low ecological risk of $\mathrm{Pb}$ in Leizhou Peninsula. However, $\mathrm{Pb}$ content is higher in the Lianjiang and Suixi districts, which may be related to marine pollution, aquaculture, and mining activities in these areas.

Mangrove sediments commonly retain heavy metals (MacFarlane and Burchett, 2002). Numerous mangrove species, including Avicennia, Rhizophora, and Kandelia spp., also are capable of accumulating predominantly such metals as $\mathrm{Cu}, \mathrm{Zn}, \mathrm{Pb}, \mathrm{Fe}, \mathrm{Mn}$, and $\mathrm{Cd}$ in their roots (Zhong et al., 2010). Because heavy metals do not degrade biologically, they are transferred and concentrated from soils into plant tissues and have long-term damaging effects on plants. Nevertheless, different plants react differently to trace metals, such that some are more resistant to heavy metals. Large accumulations of heavy metals not only exert deleterious effects on plant growth, but also affect soil microbial communities and soil fertility (Kandeler et al., 1996; Yim and Tam, 1999).

\subsection{Joint effects of habitat variables on mangrove community assembly}

Habitat variables affect all mangrove species assemblies in overstory and understory vegetation. Plant species' responses to habitat factors depend on establishment opportunities, environmental tolerances, and interspecific interactions (Adriano, 1986; Dragovic et al., 2008;
Rumisha et al., 2012), all of which can be affected by habitat variables. Friess showed that sediment variables are related to sediment supply from upland land use, erosion processes, and water flows at landscape scales (Friess et al., 2012). In addition, rich sulfide, high organic matter content, and salinity are believed widely to be the main factors responsible for the retention of water-borne heavy metals in mangrove sediment (Qiu et al., 2011; Bayen, 2012; Liu et al., 2014). These are likely to be the reasons for the joint effects of habitat physicochemical and sediment metals variables.

\section{Conclusion}

Effective conservation of mangroves requires a complete understanding of their vegetation structure and identification of the most important variables that affect them. Leizhou Peninsula shelters the largest natural mangrove reservoir in China. In this study, we found seven species in the overstory and ten species in the understory at twenty-six sites in Leizhou Peninsula, China. However, 6 species in the overstory and 7 in the understory were left for analysis of SIV. Using CCA, we determined the independent and joint effects of physicochemical characteristics and heavy metals in sediments on mangrove assemblies, and conducted repeated analyses in overstory and understory mangrove vegetation, respectively. The results indicated that habitat physicochemical variables and sediment metals explained a significant amount of the variation in species assembly among the sites. Contributions of sediment physicochemical variables to species assembly were greater than were those of heavy metals, especially in the overstory. However, the independent contributions of heavy metals were greater in understory mangrove vegetation than in overstory. Further, there were overlapping contributions of sediment physicochemical variables and heavy metals for mangrove assemblies in overstory and understory vegetation, respectively. The TOC, TP, and salinity of the sediment, distance from the coastline, and concentration of As were limiting factors for species assembly in overstory vegetation, while understory vegetation may be affected to a greater degree by the distance from the coastline, EC, and concentrations of $\mathrm{As}$ and $\mathrm{Pb}$ in the sediment. Therefore, to facilitate successful mangrove conservation, sediment variables should be considered in relation to mangrove vegetation structure.

\section{Acknowledgements}

This work was supported by the National Science and Technology Projects in the 12th Five-Year Program, P.R. China (Grant No. 2012BAC07B04). Additional support for fieldwork was provided by the South China Botanical Garden, the Chinese Academy of Sciences, the Institute of Urban Environment, the Chinese Academy of Sciences, and the Zhanjiang Mangrove National Nature Reserve. We also wish to express our gratitude to Peihong Zhao, Bingbing Wang, Fushuai Zhang, and Jinya Li for their technical assistance at various stages of the research.

\section{References}

Adriano, D.C., 1986. Trace Elements in the Terrestrial Environment. SpringerVerlag, New York.

Alatalo, R.V., 1981. Problems in the measurement of eveness in ecology. Oikos 37 199-204.

Armitage, A.R., Boyer, K.E., Vance, R.R., Ambrose, R.F., 2006. Restoring assemblages of salt marsh halophytes in the presence of a rapidly colonizing dominant species. Wetlands 26, 667-676.

Bayen, S., 2012. Occurrence, bioavailability and toxic effects of trace metals and organic contaminants in mangrove ecosystems: a review. Environ. Int. 48, 84-101.

Carbonell, A.A., Aarabi, M.A., DeLaune, R.D., Gambrell Jr., R.P., P., W.H., 1998. Bioavailability and uptake of arsenic by wetland vegetation: effects on plant growth and nutrition. J. Environ. Sci. Health 33, 45-66.

Dahdouh-Guebas, F., Kairo, J.G., Jayatissa, L.P., Cannicci, S., Koedam, N., 2002. An ordination study to view vegetation structure dynamics in disturbed and undisturbed mangrove forests in Kenya and Sri Lanka. Plant Ecol. 161, 123-135. 
Dragovic, S., Mihailovic, N., Gajic, B., 2008. Heavy metals in soils: distribution, relationship with soil characteristics and radionuclides and multivariate assessment of contamination sources. Chemosphere 72, 491-495.

Duke, N.C., 2001. Gap creation and regenerative processes driving diversity and structure of mangrove ecosystems. Wetl. Ecol. Manag. 9, 257-269.

Duke, N.C., Meynecke, J., Dittmann, S., Ellison, A.M., Anger, K., Berger, U., Cannicci, S., Diele, K., Ewel, K.C., Field, C., Koedam, N., Lee, S.Y., Marchand, C., Nordhaus, I., DahdouhGuebas, F., 2007. A world without mangroves? Science 317, 41-42.

Feller, I.C., 1995. Effects of nutrient enrichment on growth and herbivory of dwarf red mangrove (Rhizophora mangle L.). Ecol. Monogr. 65, 477-505

Friess, D.A., Krauss, K.W., Horstman, E.M., Balke, T., Bouma, T.J., Galli, D., Webb, E.L., 2012. Are all intertidal wetlands naturally created equal? Bottlenecks, thresholds and knowledge gaps to mangrove and saltmarsh ecosystems. Biol. Rev. 87, 346-366.

Fromard, F., Puig, H., Mougin, E., Marty, G., Betoulle, J.L., Cadamuro, L., 1998. Structure, above-ground biomass and dynamics of mangrove ecosystems: new data from French Guiana. Oecologia 115, 39-53.

Gan, H.Y., Lin, J.Q., Liang, K., Li, F., Duan, Z.P., 2014. Distribution and ecological risk assessment of heavy metals in the surface sediments of the coastal wetland on the Leizhou Peninsular (in chinese). J. Trop. Oceanogr. 33, 79-87.

Gao, X.M., Han, W.D., Liu, S.Q., 2009. The mangrove and its conservation in Leizhou Peninsula, China. J. For. Res. 20, 174-178.

Giesen, W., Wulffraat, S., Zieren, M., Scholten, L., 2007. Mangrove Guidebook for Southeas Asia. Food and Agricultural Organisation and Wetlands International, Bangkok, Thailand.

Kandeler, E., Kampichler, C., Horak, O., 1996. Influence of heavy metals on the functional diversity of soil microbial communities. Biol. Fertil. Soils 23, 299-306.

Kao, W.Y., Tsai, H.C., Tsai, T.T., 2001. Effect of $\mathrm{NaCl}$ and nitrogen availability on growth and photosynthesis of seedlings of a mangrove species, Kandelia candel (L.) Druce. J. Plant Physiol. 158, 841-846.

Koch, M.S., Snedaker, S.C., 1997. Factors influencing Rhizophora mangle L. seedling development in Everglades carbonate soils. Aquat. Bot. 59, 87-98.

Krauss, K.W., Lovelock, C.E., McKee, K.L., López-Hoffman, L., Ewe, S.M.L., Sousa, W.P., 2008. Environmental drivers in mangrove establishment and early development: a review. Aquat. Bot. 89, 105-127.

Krishna Prasad, M.B., Ramanathan, A.L., 2008. Sedimentary nutrient dynamics in a tropical estuarine mangrove ecosystem. Estuar. Coast. Shelf Sci. 80, 60-66.

Kristensen, E., Bouillon, S., Dittmar, T., Marchand, C., 2008. Organic carbon dynamics in mangrove ecosystems: a review. Aquat. Bot. 89, 201-219.

Lara, R.J., Cohen, M.C.L., 2006. Sediment porewater salinity, inundation frequency and mangrove vegetation height in Braganç, North Brazil: an ecohydrology-based empirical model. Wetl. Ecol. Manag. 14, 349-358.

Laura, L.H., David, D.A., Niels, P.R.A., Jeanne, L.D., Miguel, M.-R., 2007. Gap-dependence in mangrove life-history strategies: a consideration of the entire life cycle and patch dynamics. J. Ecol. 95, 1222-1233.

Lepš, J., Šmilauer, P., 2003. Multivariate Analysis of Ecological Data Using CANOCO. Cambridge University Press, Cambridge, UK.

Li, N., Chen, S.L., Zhou, X.Y., Li, C.Y., Shao, J., Wang, R.G., Fritz, E., Hüttermann, A., Polle, A., 2008. Effect of $\mathrm{NaCl}$ on photosynthesis, salt accumulation and ion compartmentation in two mangrove species, Kandelia candel and Bruguiera gymnorhiza. Aquat. Bot. 88, 303-310.

Li, G.X., Xu, G.R., Shen, C.C., Tang, Y., Zhang, Y.X., Ma, K.M., 2016. Contrasting elevational diversity patterns for soil bacteria between two ecosystems divided by the treeline. Sci. China Life Sci. 59, 1177-1186.

Lin, P., 1987. The Mangrove Ecosystem in China. Science Press, Beijing.

Liu, J.L., Wu, H., Feng, J.X., Li, Z.J., Lin, G.H., 2014. Heavy metal contamination and ecological risk assessments in the sediments and zoobenthos of selected mangrove ecosystems, South China. Catena 119, 136-142.

Lovelock, C.E., Feller, I.C., Ball, M.C., Engelbrecht, B.M., Ewe, M.L., 2006. Differences in plant function in phosphorus- and nitrogen-limited mangrove ecosystems. New Phytol. $172,514-522$

MacDonald, D.D., Ingersoll, C.G., Berger, T.A., 2000. Development and evaluation of consensus-based sediment quality guidelines for freshwater ecosystems. Arch. Environ. Contam. Toxicol. 39, 20-31.
MacFarlane, G.R., Burchett, M.D., 2002. Toxicity, growth and accumulation relationships of copper, lead and zinc in the grey mangrove Avicennia marina (Forsk.) Vierh. Mar. Environ. Res. 54, 65-84.

Machado, W., Moscatelli, M., Rezende, L.G., Lacerda, L.D., 2002. Mercury, zinc, and copper accumulation in mangrove sediments surrounding a large landfill in southeast Brazil. Environ. Pollut. 120, 455-461.

Matthews, J.W., Peralta, A.L., Flanagan, D.N., Baldwin, P.M., Soni, A., Kent, A.D., Endress, A.G., 2009. Relative influence of landscape vs. local factors on plant community assembly in restored wetlands. Ecol. Appl. 19, 2108-2123.

Mckee, K.L., 1995. Seedling recruitment patterns in a Belizean mangrove forest - effects of establishment ability and physicochemical factors. Oecologia 101, 448-460.

Minchinton, T.E., 2001. Canopy and substratum heterogeneity influence recruitment of the mangrove Avicennia marina. J. Ecol. 89, 888-902.

Oksanen, J., Blanchet, F.G., Kindt, R., Legendre, P., 2013. vegan: Community Ecology Package. R Package Version 2.0-7.

Parker, V.T., 1997. The scale of successional models and restoration objectives. Restor. Ecol. 5, 301-306.

Qiu, Y.W., Yu, K.F., Zhang, G., Wang, W.X., 2011. Accumulation and partitioning of seven trace metals in mangroves and sediment cores from three estuarine wetlands of Hainan Island, China. J. Hazard. Mater. 190, 631-638.

Quaghebeur, M., Rengel, Z., 2005. Arsenic speciation governs arsenic uptake and transport in terrestrial plants. Microchim. Acta 151, 141-152.

Romero, I.C., Jacobson, M., Fuhrman, J.A., Fogel, M., Capone, D.G., 2012. Long-term nitrogen and phosphorus fertilization effects on $\mathrm{N}_{2}$ fixation rates and nifH gene community patterns in mangrove sediments. Mar. Ecol. 33, 117-127.

Rumisha, C., Elskens, M., Leermakers, M., Kochzius, M., 2012. Trace metal pollution and its influence on the community structure of soft bottom molluscs in intertidal areas of the Dar es Salaam coast, Tanzania. Mar. Pollut. Bull. 64, 521-531.

Satyanarayana, B., Raman, A.V., Dehairs, F., Kalavati, C., Chandramohan, P., 2002. Mangrove floristic and zonation patterns of Coringa, Kakinada Bay, East Coast of India. Wetl. Ecol. Manag. 20, 25-39.

Stephen, A.H., Han, Y.H.C., 2008. Fire, logging, and overstory affect understory abundance, diversity, and composition in boreal forest. Ecol. Monogr. 78, 123-140.

Streever, B., Zedler, J., 2000. To plant or not to plant. Bioscience 50, 188-189.

Suárez, N., Medina, E., 2005. Salinity effect on plant growth and leaf demography of the mangrove, Avicennia germinans L. Trees 19, 722-728.

Tam, N.F.Y., Wong, Y.S., 2000. Spatial variation of heavy metals in surface sediments of Hong Kong mangrove swamps. Environ. Pollut. 110, 195-205.

Thampanya, U., Vermaat, J., Duarte, C., 2002. Colonization success of common Thai mangrove species as a function of shelter from water movement. Mar. Ecol. Prog. Ser. 237, 111-120.

Tomlinson, P.B., 1986. The Botany of Mangroves. Cambridge University Press, New York.

Wang, W.Q., Wang, M., 2007. The Mangroves of China. Science Press, Beijing.

Ye, Y., Gu, Y.T., Gao, H.Y., Lu, C.Y., 2010. Combined effects of simulated tidal sea-level rise and salinity on seedlings of a mangrove species, Kandelia candel (L.) Druce. Hydrobiologia 641, 287-300.

Yim, M.W., Tam, N.F., 1999. Effects of wastewater-borne heavy metals on mangrove plants and soil microbial activities. Mar. Pollut. Bull. 39, 179-186.

Zhang, Y.E., Deng, A.Y., Zhuang, T.C., Lin, P., 2003. Relation between soil salinity in intertidal zone and electric conductivity (in Chinese). Ecol. Environ. 12, 164-165.

Zhang, Y.X., Ma, K.M., Anand, M., Fu, B.J., 2006. Do generalized scaling laws exist for species abundance distribution in mountains? Oikos 115, 81-88.

Zheng, W.J., Lin, P., 1990. Effect of salinity on the growth characteristics and water metabolism of seedlings of Kandelia candel. Journal of Xiamen University (Natural Science) 29, 575-579

Zhong, Z.Y., Lin, K., Tam, N.F.Y., 2010. Lead stress in seedlings of Avicennia marina, a common mangrove species in South China, with and without cotyledons. Aquat. Bot. 92, 112-118. 